\title{
Environmental Scanning Practices in an Emerging Market: A Case in Malaysian Hotels
}

\author{
Haliza Mohd Said ${ }^{a *}$, Sayeed Siddiq ${ }^{\mathrm{b}}$, Nor KhomarIshak ${ }^{\mathrm{b}}$ \\ aUNITAR International University \\ bUniversity Tun Abdul Razak \\ lizasaid@unitar.my
}

\begin{abstract}
The purpose of this study is to investigate how hotels in Malaysia conduct Environmental Scanning activities in order to manage changing market structures. Environmental Scanning activities offer a strategic information approach whereby the organisation will be able to store information, recognize prospects for growth and discover ways to improve operational competence. A qualitative approach was adopted using in-depth interviews on eight 5-star hotels in Malaysia. The finding provides a better understanding of the environmental scanning activities and the types of information collected by hotels in Malaysia. It was evident from the findings, the type of industry affects the content of what was scanned. With this understanding of the environmental scanning in the hotel industry, the top-level management is able to enhance their decisionmaking capabilities in strategic planning.
\end{abstract}

Keywords: Environmental Scanning, Business Environment, Scanning System, Malaysian Hotels, Emerging Market

\section{INTRODUCTION}

Malaysia's drive to develop a world-class infrastructure driven it to be one of the top five in a closely watched leading emerging markets (New Straits Times, 2016). Tourism industry is the third highest Gross National Income (GNI) contributor to the country's Gross Domestic Production (Lean and Tang, 2010). In order for Malaysia to sustain its economic well-being, it has to continue to attract tourist arrival to the country.

Accommodation sector in particular hotels in Malaysia has played a vital role in generating income for the country. Hotel sectors are the drivers of growth for travel and tourism industry in Malaysia. In Malaysia, the hospitality industry has experienced a positive increase consistent with the growth of global hospitality industry in recent years(Ministry of Tourism Malaysia, 2009). Despite the slower growth of Malaysia economy due to global economic crisis, the tourism industry has rebounded quickly. The performance of hotel operational system can have strong influence on the firms, the employee, and the customers (Tsaur and Lin, 2004; Barros, 2005). Therefore, the hospitality firms shouldbe in touch with the markets in terms of recent trends and changes (Dupre and Lane, 1997). They need to have thorough understanding of hospitality industry so that they can build competitive strategy(Claver and Pereira, 2006).

The research objective is to find out how hotel organisations conduct environmental scanning activities in collecting, compiling, cataloguing, storing, retrieving and disseminating information for decision making purposes. The research further explores the possible patterns of environmental scanning process among the hotels. This would answer how hotels conduct their environmental scanning process.

\section{LITERATURE REVIEW}

In a related study by Hough and White (2004), who viewed environmental scanning as a process of (i) identifying, (ii) collecting, (iii) processing, and (iv) translating information about external environmental 
influences into useful plans which could then be used to support decisions for the organisation. Iadele (2006) defined environmental scanning as the process of dealing with the measurement, forecasting and evaluation of changes in the different environment variables. Thompson (1967), also mentioned that environmental scanning was a process by which the executives assessed the trends and events outside the organisation. Thus, the environmental scanning process would be an important step towards the strategic planning process; whereby emerging trends, changes and issues are regularly monitored and evaluated so as to identify the impact on business decisions (Preble et. al, 1988).

Lester and Waters (1989), defined environmental scanning as the management procedure of using information from the environment to assist in decision making through the process of obtaining, analysing and using relevant information. This is in support of Aguilar's (1967) landmark study which proposed that the process of environmental scanning had to be integrated into the organisation's information management system in order to be effective.

Many organisations today are developing different types of strategies that would allow them to be increasingly sustainable in the dynamic business environment, and one way of ensuring that, would be though the establishment of a proper environmental scanning process followed by a systematic analysis of the environmental information.Information is considered important for decision-making, as it represents a bridge between the organisation and its environment and is the means by which an image of the changing environment is built up within the organisation (Babalhavaeji and Farhadpoor, 2013).

The strategic environmental scanning information system comprised of the 7 steps as defined and depicted in the following table:

\begin{tabular}{|l|l|l|}
\hline NO. & STEPS & DEFINITION \\
\hline 1 & Specify Information Needs & $\begin{array}{l}\text { Nishi et al. (1982), specified the information needs as the selection of } \\
\text { key environment variables that would be critical to the firm's external } \\
\text { environment. }\end{array}$ \\
\hline 2 & Specify Information Sources & $\begin{array}{l}\text { Nishi et al. (1982), specified the information sources as either formal } \\
\text { or informal, such as publications, trade meetings, the establishment } \\
\text { of information network of affiliations though suppliers, distributors, } \\
\text { and subsidiaries from which the scanning unit would seek information } \\
\text { routinely. }\end{array}$ \\
\hline 3 & Compile Information & $\begin{array}{l}\text { Eisenberg et al. (2008), defined the compilation of information as the } \\
\text { process involved in differentiating facts from opinions; comparisons of } \\
\text { similar characteristics; the various interpretations (versions) of data, } \\
\text { seeking more information, if needed; and the organization of logical } \\
\text { ideas and information. Clark (1991), further indicated that these were } \\
\text { accomplished through the use of microcomputers, optical disks, magnetic } \\
\text { disk-storage media, computer graphics and search engines in online } \\
\text { catalogues, ease information search. }\end{array}$ \\
\hline 4 & Catalogue Information & $\begin{array}{l}\text { Adapting Clark's (1991) definition on cataloguing, could be better } \\
\text { understood as the process of separating the compiled information into } \\
\text { parts are prioritized into headings and subheadings according to topics. }\end{array}$ \\
\hline 5 & Store Information & $\begin{array}{l}\text { Adapting Aaker's (1983), definition of storing information, the process } \\
\text { could include a simple set of files or a sophisticated computer-based } \\
\text { information as used in the compilation and retrieval system. }\end{array}$ \\
\hline
\end{tabular}




\begin{tabular}{|l|l|l|}
\hline \hline 6 & Retrieve Information & $\begin{array}{l}\text { Gonzalez (2008), defined the retrieval process as the application of } \\
\text { Digital libraries, Information filtering processes, or through Media search } \\
\text { engines to derive the required information. }\end{array}$ \\
\hline 7 & Disseminate Information & $\begin{array}{l}\text { Indyk and Rier, 1993; Dentler, 1984); Edward, 1991; and Klien and } \\
\text { Gwaltney,1991 defined the dissemination of information by circulating } \\
\text { reports to be used for strategic planning, budgetary or for operational } \\
\text { planning sessions which might be in the form of memorandum statements, } \\
\text { budgetary information/data, bulletin/newsletter articles, industry trends, } \\
\text { and/or market analysis reports. }\end{array}$ \\
\hline
\end{tabular}

Based on the literature review, the development of ES concept was found in landmark studies during 1980s to 1990's i.e. Aaker (1983), Byars (1987), Daft et al. (1988), Fahey et al. (1981), Jain (1984), Nishi et al. (1982), Smeltzer et al. (1988), Burack and Mathys (1989), Lester and Waters (1989), Choo \& Auster (1993), Choo (1998). However, between 1990s and 2010, studies on Environmental Scanning model has further examined the concept and develop conceptual models. Minimal literature was found on integrated model during 2011 to 2016. The Literature Review concentration of Environmental Scanning research is on organization strategy and organization performance and minimal literature were found on how organization collect, compile, catalogue, store, retrieve and disseminate information.

Daft (1988), Aaker (1983), Doyle (1994), Choo (2001), Albright (2004), and Zhang, et al. (2011), proposed many different approaches to scanning. The different approaches posed some difficulties in establishing an acceptable measurement. According to these researchers, it was difficult to establish the scanning measures as the executives tended to scan in informal and casual ways.

Aaker (1983), developed Strategic Environmental Scanning Information System Model. The model provided a simplistic 6-step process which began with the identification of information needed, identification of information sources, identify participants, assign scanning tasks, storage and processing of information and dissemination of the information. Aaker proposed a strategic scanning system to provide useful strategic information at a low cost when needed, it focuses on target information needs, allocates effort among those exposed to relevant information, and provides an effective system for storing, processing and disseminating information. A formal and simple strategic information scanning system may improve the effectiveness of the scanning effort and preserve much of the information that may go missing to the organization. Such loss of information due to undirected scanning efforts, whereby participants are not partitioned, scanning activities are not performed adequately and there is an absence of a medium to store, subsequently retrieve and disseminate information.

Similarly, Daft (1988), in developing a model based on the Environment Information Process suggested that the environmental scanning process follow a 6-step continuous process. The six steps are (i) Scanning Needs Identification, (ii) Information Acquisition, (iii) Information Processing and Synthesizing, (iv) Information Organization and Storage, (v) Information Distribution and (vi) Information Evaluation and Use. Daft's model states that senior managers' perceived strategic uncertainties would determine the scanning frequency and mode. Besides information acquisition, identification of information needs and information distribution would also be influenced by perceived uncertainty levels which remain unexplored. This model failed to consider the role of literacy skills in environmental scanning as well as the employees' participation. A refined model has been proposed to address the limitation of Daft's model and has been developed based on a formal six-step environmental scanning process conducted to fulfil the top management's need for strategic decision making. In this refined model, equal importance has been placed on the scanning steps beginning from "scanning needs identification" to "information evaluation and use". Besides acknowledging senior managers' directing the various roles in the whole process, employees participating in environmental scanning are also covered through the influence of information literacy skills on conducting scanning activities. 
Environmental Scanning Practices in an Emerging Market: A Case in Malaysian Hotels

Further to that, Doyle (1994), has suggested a Systematic Approach to being Information Literate Model which comprised of 10 steps. The first step is to (i) recognize need for Information; (ii) recognize need for accurate and complete information; (iii) formulate questions based on needs, (iv) identify potential sources of information; (v) develop successful search strategies, (vi) access sources including computer based and other technology, (vii) evaluate information, (viii) organize information for practical application, (ix) integrate new information into existing body of knowledge, and (x) use information in critical thinking and problem-solving.

Choo (2001), further explained the steps required to perform formal scanning. At a first step, it was necessary to identify the scanning needs. This was followed by the process of collecting information and then analyzing them. The results were then communicated to the relevant personnel, and decisions would be made based on the information. The formal environmental scanning process starts with clearly defined scanning needs. Organizations actively collect environmental information through various channels and sources. The collected information is either stored for future use or processed and synthesized with the existing organizational knowledge. After filtering (the process of removing the irrelevant parts of the information, repacking (selecting information from different sources and compiling such information) or interpreting (analyzing and adding organizational context and meaning to the collected information based on understanding), the processed environmental intelligence may be organized and stored in an organization repository for future reference or disseminated directly to target users.

Albright (2004) has proposed a simplified 5 steps in Environmental Scanning Process. The process starts with identifying the needs to conduct the scanning of information. This is followed by the actual act of gathering information from the environment; the information may be general information, task information or specific information. Once the information has been gathered, the information will go through analysis process where the data will be analysed as an objective information. This intelligence information need to be communicated to the top managers to assist them to make decision and strategize for the organization.

Zhang, et al. (2011), further explained a Model on Environmental Scanning Process which was based on Choo's (2001) model. The difference was in the increased volume of feedback and review process that would be carried out at each step. Unlike Choo's information management model, Zhang et al. (2011), defined environmental scanning as that which ends at information evaluation and use (evaluating and using the collected and processed external environmental information for assisting tactical and strategic decision making). The step 'information products/service' is replaced with 'information processing and synthesizing', which can provide a clearer picture of the systematic scanning process. Upon receipt, the end-users may evaluate its quality, such as timeliness, relevance and accuracy and use these factors for assisting in tactical or strategic decision making. If an end-user's information need is not satisfied, a new round of acquisition, processing and distribution will take place. At times, steps like 'information processing and synthesizing' and 'information distribution' may be avoided due to certain factors such as fulfilling urgent information needs which require fast action, or due to a lack of human resource or the information collector will use knowledge without sharing with the others.

\section{ReSEARCH Methodology}

This research is considered as an exploratory study since there is little research previously done on the Malaysia hospitality (Jennings, 2001). The method used in this research is qualitative method. Jennings (2001) has suggested that qualitative method is applied in exploratory study because of the flexibility of data collection approaches. Furthermore, this type of study is not based on random sampling and representation of a study's population. Moreover, qualitative method is used to explore the perspectives, experiences, attitudes, and belief of the respondents (Holloway, 1997).

The unit of analysis in this study is made up of the hotelas a whole and the specified unit/department that would be involved in the environmental scanning activities of the hotel. At the hotel level, the respondent is the general manager or the chief executive officer, who are the highest authority in determining the scope 
and magnitude of the external environment forces that could have an impact on the hotel's internal system, structure and processes. At the unit/department level, the general manager or chief executive officer indicates which unit or department would directly be involved in the environment scanning activities. Thus, the second respondent would be determined by the general manager or chief executive officer.

Before the process of selecting the hotels to be investigated, the following criteria were established: (i) two groups of hotels based on the location would be required (resorts and city hotels): (ii) the hotels had to be rated 5-star; (iii) had been in operation for at least 2 years; (iv) and had a minimum of 100 rooms; and that each group had to consist of at least 3 hotels.

The study has adopted an in-depth interview supported by a set of semi structured questions composed of open ended questions. The interview sessions were tape recorded after securing permission to do so. The questions were in the form of semi-structured questions composed of open ended questions to allow the researcher to collect and probe further, so as to ascertain the accurateness of the data/information.

The primary data that was used for this study comprised of information from the in-depth interview on the: (i) profile background of the respondent, (ii) profile background of the organisation, (iii) environmental scanning system, (iv) environmental scanning structure, (v) environmental scanning process, and (vi) strategic environment scanning information system. The secondary data that was used for this study comprised of information on each hotel that was derived from published research surveys (thesis and journal articles), unpublished dissertation reports, published data on statistical economic reports and information on the hospitality industry by Tourism Malaysia, Ministry of Tourism Malaysia, and the Malaysian Association of Hotels.

\section{FINDINGS}

Based on the findings from the in-depth interviews, patterns were identified for all 7 steps of environmental scanning process among hotels in Malaysia. The following explain all the process:

\section{Information Needed}

The following table shows that all the factors in this category that are significant as identified by both the City and Resort hotel groups. Both groups scanned the task environment rather than the general environment and specific environment at the national/local levels. Both groups used formal and informal sources for scanning. All departments, especially the Level 1 (General Manager, Directors) employees were responsible for identifying the information needed. Both groups were in the Reactive Phase in the scanning mode. Both groups adopted the Investigation scanning approach. More than 5 hours per week were spent on the selection of information needed, which was conducted on a continuous basis.

\begin{tabular}{|l|l|l|}
\hline No & Factors & Patterns Identified \\
\hline 1 & Environment Information & $\begin{array}{l}\text { Scanned task environment rather than the general environment } \\
\text { and specific environment. }\end{array}$ \\
\hline 2 & Mode of Information Scanned & Both Formal and Informal \\
\hline 3 & Departments/Units Responsible & All departments \\
\hline 4 & Employee Responsibility & Level 1 Employee: General Manager, Directors. \\
\hline 5 & Scanning Mode & Reactive \\
\hline 6 & Scanning Approach & Investigation \\
\hline 7 & Time Spent & More than 5 hours per week \\
\hline 8 & Regularity & Continuous \\
\hline
\end{tabular}

American Research Journal of Business and Management

Page 5 


\section{Information Sources}

The following table shows that all the factors in this category were significant as identified by both the City and Resort hotel groups. Both groups generally used formal sources, however when identifying the types of sources used, the informal information sources appeared to be more significant. Types of informal sources used were family and friends, personal networking and, competitor friends, and social media. The relevant departments, especially the Level 1 (General Manager, Directors), Level 2 (Head of Departments, Managers) and Level 3 (Assistant Managers, Coordinators, Supervisors) employees were responsible for identifying information sources. There was no proper sequence in the steps taken in the selection of information sources.

\begin{tabular}{|l|l|l|}
\hline No & Factors & Patterns Identified \\
\hline 1 & $\begin{array}{l}\text { Sources of Information most } \\
\text { used }\end{array}$ & $\begin{array}{l}\text { Comparisons between Formal and Informal information sources were } \\
\text { used, the use of formal information was utilized more. However, when } \\
\text { identifying the types of sources used, the informal information sources } \\
\text { appeared to be more significant. The types of formal sources used } \\
\text { varied and none were found to be significant }\end{array}$ \\
\hline 2 & Types of Informal Sources & $\begin{array}{l}\text { Comprised of family and friends, personal networking and, competitor } \\
\text { friends, and social media. }\end{array}$ \\
\hline 3 & Department/Unit Responsible & Relevant departments \\
\hline 4 & Employee Responsible & $\begin{array}{l}\text { Level 1: General Manager, Directors } \\
\text { Level 2: Head of Departments, Managers } \\
\text { Level 3: Assistant Managers, Coordinators, Supervisors }\end{array}$ \\
\hline 5 & $\begin{array}{l}\text { Steps in Selecting Information } \\
\text { Sources }\end{array}$ & No proper sequence \\
\hline
\end{tabular}

\section{Compile Information}

The following table shows that all the factors in this category are significant as identified by both the City and Resort hotel groups. Both groups had no dedicated system to compile information; the hotels mainly used inhouse application software. Reports were the preferred method of compiling. Sales and Marketing departments, especially the Level 2 (Head of Departments, Managers) and Level 3 (Assistant Managers, Coordinators, Supervisors) employees were responsible for compiling information. Steps in compiling were based on the identification of topics. There was no proper sequence in the steps taken in compiling information. More than 5 hours per week were spent on compiling information.

\begin{tabular}{|l|l|l|}
\hline No & Factors & Patterns Identified \\
\hline 1 & Compilation System & No dedicated system, mainly used in-house application software. \\
\hline 2 & Modes/Method for Compiling & Mainly relied on Reports \\
\hline 3 & Departments/Units Responsible & Sales and Marketing Department \\
\hline 4 & Employee Responsible & $\begin{array}{l}\text { Level 2: Head of Departments, Managers } \\
\text { Level 3: Assistant Managers, Coordinators, Supervisors }\end{array}$ \\
\hline 5 & Steps in Compiling Information & Only in the identification of Topics \\
\hline 6 & Time Spent & More than 5 hours per week \\
\hline
\end{tabular}

American Research Journal of Business and Management 
Environmental Scanning Practices in an Emerging Market: A Case in Malaysian Hotels

\section{Catalogue Information}

The following table shows that all the factors in this category are significant as identified by both the City and Resort hotel groups. Both groups did not carry out the cataloguing of information. There were no activities related to catalogue information conducted.

\begin{tabular}{|l|l|l|}
\hline No & Factors & Patterns Identified \\
\hline 1 & System used & \\
\hline 2 & Modes/Methods for Cataloguing & \\
\hline 3 & Departments/Units Responsible & \\
\hline 4 & Employees Responsible & \\
\cline { 1 - 2 } & Steps in Cataloguing information & \\
\cline { 1 - 2 } & Time Spent & \\
\end{tabular}

\section{Store Information}

The following table shows that all the factors in this category are significant as identified by both the City and Resort hotel groups. Both groups did not use any system to store information. Hard copy and Soft copy documents were used to store information. Staff Passwords to access into the in-house systems were used as the security system to store information. Relevant departments, especially the Level 2 (Head of Departments, Managers) and Level 3 (Assistant Managers, Coordinators, Supervisors) employees were responsible for storing information. There were two significant steps involved in storing of information: i) Key-in soft copy documents and ii) Filing-in hard copies.

\begin{tabular}{|l|l|l|}
\hline No & Factors & Patterns Identified \\
\hline 1 & Systems Used & No system was used \\
\hline 2 & Types of Storage Used & Hard copy and Soft copy documents \\
\hline 3 & Security System Installed & Staff Password to access into the in-house system \\
\hline 4 & Departments/Units Responsible & Relevant Departments \\
\hline 5 & Employees Responsible & $\begin{array}{l}\text { Level 2: Heads of Departments, Managers } \\
\text { Level 3: Assistant Managers, Coordinators, Supervisors }\end{array}$ \\
\hline 6 & Steps in Storing Information & $\begin{array}{l}\text { Two significant steps in storing: } \\
\text { Key-in soft copy documents } \\
\text { Filing-in hard copies }\end{array}$ \\
\hline
\end{tabular}

\section{Retrieve Information}

The following table shows that all the factors in this category are significant as identified by both the City and Resort hotel groups. Both groups had no system set in place to retrieve information. Verbal and Non-verbal communication were used as a method to retrieve information via hard copy and soft copy formats. Information retrieved was mainly used for Budget meetings and Sales Promotions. Relevant departments, especially the Level 1 (General Manager, Directors), Level 2 (Head of Departments, Managers) and Level 3 (Assistant Managers, Coordinators, Supervisors) employees were responsible for retrieving information. Channels for Retrieving Information were Face-to-face during briefings and meetings. Steps in retrieving were only carried out via requests through e-mails or during briefings. 
Environmental Scanning Practices in an Emerging Market: A Case in Malaysian Hotels

\begin{tabular}{|l|l|l|}
\hline No & Factors & Patterns Identified \\
\hline 1 & System Used & No systems were used \\
\hline 2 & Modes/Methods for Retrieving Information & $\begin{array}{l}\text { Verbal and Non-verbal (Detail on types: Refer to } \\
\text { Dissemination of Information in the following step) }\end{array}$ \\
\hline 3 & Forms/Format for Retrieving Information & Hard copies and Soft copies \\
\hline 4 & Use of Retrieved Information & Budget meetings and Sales Promotions \\
\hline 5 & Departments/Units Responsible & Relevant Departments \\
\hline 6 & Employee Responsible & $\begin{array}{l}\text { Level 1: General Manager, Directors } \\
\text { Level 2: Head of Departments, Managers } \\
\text { Level 3: Assistant Managers, Coordinators, Supervisors }\end{array}$ \\
\hline 7 & Channels of Retrieving Information & Face-to-face during briefings and meetings \\
\hline 8 & Steps for Retrieving Information & Requests through e-mails or during briefings \\
\hline
\end{tabular}

\section{Disseminate Information}

The following table shows that all the factors in this category were significant as identified by both the City and Resort hotel groups. Both groups have no system in place to disseminate information. Verbal communication was used as a method to disseminate information via reports, hard copies and soft copies. Information retrieved was mainly used for Budget meetings and briefings. Relevant departments, especially at Level 1 (General Manager, Directors) and Level 2 (Head of Departments, Managers) employees were responsible for disseminating information. Oral communication during briefings and meetings were used to disseminate information. Channels for disseminating Information were face-to-face briefings and meetings. There were three significant steps involved in disseminating information: i) Determine information required, ii) Identification of the person who requested for the information and iii) Identification of channels to disseminate information.

\begin{tabular}{|c|c|c|}
\hline No & Factors & Patterns Identified \\
\hline 1 & Disseminating Systems Used & No system used \\
\hline 2 & $\begin{array}{l}\text { Modes/Methods for Disseminating } \\
\text { Information }\end{array}$ & Verbal \\
\hline 3 & $\begin{array}{l}\text { Forms/Formats used in Disseminating of } \\
\text { Information }\end{array}$ & Reports, Hard copies and Soft copies \\
\hline 4 & Venues for Disseminating Information & Budget meetings and briefings \\
\hline 5 & Departments/Units Responsible & Relevant Departments \\
\hline 6 & Employees Responsible & $\begin{array}{l}\text { Level 1: General Manager, Directors } \\
\text { Level 2: Head of Departments, Managers }\end{array}$ \\
\hline 7 & $\begin{array}{l}\text { Types of Methods used in Disseminating } \\
\text { Information }\end{array}$ & Oral communication during briefings and meetings \\
\hline 8 & Channels for Disseminating Information & Face-to-face during briefings and meetings \\
\hline 9 & Steps for Disseminating Information & $\begin{array}{l}\text { Three significant steps were identified:- } \\
\text { Determine information required } \\
\text { Identification of who Requested for the information } \\
\text { Identification of channels to disseminate information }\end{array}$ \\
\hline
\end{tabular}




\section{CONCLUSION}

Environmental changes, such as changing market structures, opportunities and increasing political instability are forcing executives and organisations to collect, analyse, interpret and act on environmental information fast (Huber, 1984; Huber and McDaniel, 1986, Eisenhardt, 1989). Based on this statement, the recognition of changes' in the market, competition, technology, innovation, and customers' behavioral patterns, and the prediction of future trends are essential for healthy competition (Gabbar, 2007).

The goal of environmental scanning activity is to provide the systematic use of information and actionable intelligence that will provide a competitive edge to the organisation (Kahaner, 1997). This research is to enlighten hotel organisations of their Reactive strategy on environmental scanning practices and to assist them to upgrade their practice of information gathering which will in turn assist in strategic decision-making. Scanning systems are also known as systems that are created in response to the organisation's degree of inventiveness. These systems are intended to give a competitive edge to the organisation. These organisations could then possibly generate better products or services at a lower cost, is differentiated, and focuses on a particular market segment which is also innovative in nature.

The research has also answered the questions about how environmental scanning conducted in hotel organisations, what are process of environmental scanning involved and why hotel organisations scan the external environment. It was evident from the findings, the type of industry affects the content of what was scanned. With this understanding of the environmental scanning in the hotel industry, the top-level management is able to enhance their decision-making capabilities in strategic planning.

\section{REFERENCES}

1. Aaker, D.A. (1983). Organizing a strategic information scanning system. California Management Review, 25(2), 76-83

2. Aguilar, F.J. (1967). Scanning the Business Environment. New York, NY: MacMillan.

3. Albright, K.S., (2004). Environmental Scanning: Radar for Success. The Information Management Journal.

4. Babalhavaeji, F. and Farhadpoor, M. (2013). Information source characteristics and environmental scanning by academic library managers. Information Research, 18(1) Retrieved from http://InformationR.net/ ir/18-1/paper568.html

5. Barros, C. P. 2005. Measuring efficiency in the hotel sector. Annals of Tourism Research, 32(2): 456-477.

6. Burrack, E.H. and N.J. Mathys. (1989). “Environmental Scanning Improves Strategic Planning,”. HR Magazine, 34(4), 82-87.

7. Byars, L.L. (1987). Strategic Management: Planning and Implementation; Concepts and Cases. New York, Harper \& Row.

8. Choo, C.W.(1998a). Information Management for the Intelligent Organization: The Art of Scanning the Environment. (2nd ed.) Medford, NJ: Information Today, Inc. Retrieved from http://choo.fis.utoronto.ca/fis/imio

9. Choo, C.W., \& Auster, E., (1993) Environmental scanning by CEOs in two Canadian Industries. Journal of the American Society for Information Science, 44(4), 194 - 203.

10. Claver and Pereira, (2006). Claver-Cortés, E., Molina-Azorín, J. F., \& Pereira-Moliner, J. (2006). Strategic groups in the hospitality industry: Intergroup performance differences in Alicante, Spain. Tourism Management, 27, 1101-1116.

11. Daft, R. L., Sormunen, J. \& Parks, D. (1988). Chief executive scanning, environmental characteristics and company performance: an empirical study. Strategic Management Journal, 9(2), 123-139. 
Environmental Scanning Practices in an Emerging Market: A Case in Malaysian Hotels

12. Dupre, D. and Lane, H.E. (1997). Hospitality World : An Introduction. New York. John Wiley \& Sons.

13. Eisenhardt, K. M. (1989). Building theories from case study research. Academy of Management Review, 14(4), 532-550. Retrieved from http://www.jstor.org/stable/258557

14. Fahey, L.K., William R.K., and Narayanan, V. K. (1981). Environmental scanning and forecasting in strategic planning -the state of the art. Long Range Planning, 14, 32-39.

15. Hugh, J.R., White, W.M., (2004). "Scanning actions and environmental dynamism: Gathering information for strategic decision making". Management Decision, 42(6), 781-793. Retrieved from https://doi. org/10.1108/00251740410542348

16. Holloway, I. (1997). Basic concepts for qualitative research. Oxford: Blackwell Science.

17. ladele, O. (2006). Essentials of Marketing Management (revision ed.). Mushin, Lagos Niyak Print and Publications.

18. Jain, S. C. (1984). Environmental scanning in U.S. corporations. Long Range Planning, 17(2), 117-128.

19. Jennings, G. (2001). Tourism Research, 2nd Edition. John Wiley \& Sons, Inc.

20. Lean, H. H. and Tang, C. F. (2010), Is the tourism-led growth hypothesis stable for Malaysia? A note. International Journal Tourism Research, 12, 375-378.

21. Lester, R. and Waters, J. (1989). Environmental Scanning and Business Strategy (British Library, Research and Development Department, London, UK.

22. Ministry of Tourism Malaysia, (2009). Tourist Arrivals January - July 2009 Reached 13.35 Million. Retrived from http://www.tourismmalaysia.gov.my/corporate/research.asp?page=facts_figures.

23. New Straits Times, (2016). Malaysia at fourth spot in world emerging market logistics ranking. Retrieved from https://www.agility.com/EN/news/EMLI

24. Nishi, K., Schoderbek, C., and Schoderbek, P. (1982). Scanning the Organizational Environment: Some Empirical Results. Human Systems Management, 3(4), 233-245.

25. Preble, J. F., Pradeep A. R., and Arie, R. (1988). The Environmental Scanning Practices of US Multinationals in the Late 1980s. Management International Review, 28(4), 4 -14.

26. Smeltzer, L.R., Fann, G.L., \&Nikolaisen, V.N. (1988). Environmental scanning practices in small business. Journal of Small Business Management, 26(3), 55-62.

27. Tsaur, S.H., Lin, Y.C.(2004). "Promoting service quality in tourist hotels: the role of HRM practices and service behavior", Tourism Management, 25, 471.

28. Thompson, J. D. (1967). Organizations in Action: Social Science Bases of Administrative Theory. New York: McGraw-Hill.

29. Zhang, X., Majid, S. and Foo, S. (2011). The Contribution of ES to Organizational Performance. Singapore. Journal of Library \& Information Management, Vol. 40.

Citation: Haliza Mohd Saida, Sayeed Siddiq, Nor KhomarIshak. "Environmental Scanning Practices in an Emerging Market: A Case in Malaysian Hotels". American Research Journal of Business and Management. V4, I1; pp:1-10.

Copyright (C) 2018 Haliza Mohd Saida, Sayeed Siddiq, Nor KhomarIshak. This is an open access article distributed under the Creative Commons Attribution License, which permits unrestricted use, distribution, and reproduction in any medium, provided the original work is properly cited. 